\title{
Memperkuat Sistem Hukum Remedi Perdagangan, Melindungi Industri Dalam Negeri
}

\author{
Nandang Sutrisno \\ Dosen Fakultas Hukum UII Yogyakarta \\ E-Mail: nandst@fh.uii.ac.id
}

\begin{abstract}
Trade remedies, i.e. Anti Dumping, Anti Subsidy and Safeguard Action, are instruments of international trade prolicy that are the most frequently used by importing Member Countries of the World Trade Organization (WTO) to ptotect their domestic industries. However, Indonesia has been categorized as a Member Country which is the least frequently in the use of the instrument. This article recomemends that Indonesia employ the instrument more proactively in order to protect domestic industries. Parallel to this, dtrengthening the legal system of trade remedis is also urgent, since a strong lehal system either its substances, structures, and cultures, will play a crucial role on the effectiveness of the protection of domestic industries.
\end{abstract}

Keywords: trade remedies, strong, protection, domestic industries.

\section{Pendahuluan}

Remedi perdagangan, baik berupa Anti Dumping, Anti Subsidi maupun Tindakan Pengamanan (Safeguard), merupakan instrumen kebijakan perdagangan internasional yang paling banyak digunakan oleh negaranegara importir anggota World Trade Organization (WTO) untuk melindungi industri dalam negerinya.

Bagi Indonesia, instrumen kebijakan remedi perdagangan ini pun sangat penting untuk melindungi industri dalam negeri. Hal ini didasarkan pada alasan mengingat di satu sisi produk ekspor Indonesia seringkali dituduh merupakan produk dumping dan produk bersubsidi, dan sering juga dilakukan inisiasi untuk dikenakan tindakan pengamanan, tetapi di sisi lain Indonesia juga kebanjiran produk-produk impor dengan harga dumping dan bersubsidi dan tidak jarang mengalami lonjakan impor untuk produk-produk tertentu. Akibatnya industri dalam negeri mengalami kerugian atau terancam mengalami kerugian yang berdampak 
pada menurunnya perekonomian, dan pada gilirannya berdampak pula terhadap menyempitnya lapangan kerja atau bahkan pemutusan hubungan kerja (PHK). Ironisnya, di satu sisi Indonesia merupakan salah satu negara yang paling banyak dituduh melakukan praktek dumping, tetapi di sisi lain dikategorikan sebagai negara yang paling rendah dalam melakukan tuduhan dan penyelidikan dumping. ${ }^{1}$ Tidak mengherankan pula jika dalam penyelesaian sengketa di lembaga penyelesaian sengketa WTO, yakni Dispute Settlement Body (DSB), yang didominasi kasus-kasus remedi perdagangan, partisipasi Indonesia pun sangat minimal.

Melihat kondisi di atas, sudah merupakan keharusan bagi Indonesia untuk lebih proaktif mendayagunakan instrumen remedi perdagangan dalam rangka melindungi industri dalam negeri. Paralel dengan itu, penguatan sistem hukum remedi perdagangan juga harus dilakukan, karena sistem hukum yang kuat baik substansi, struktur maupun kulturnya, akan mempunyai peran yang krusial terhadap efektivitas perlindungan industri dalam negeri.

\section{Sekilas tentang Remedi Perdagangan}

Secara umum pengertian remedi perdagangan mengacu kepada tindakan atau kebijakan pemerintah untuk meminimalkan dampak negatif dari impor terhadap industri dalam negeri. Remedi perdagangan ini diperlukan mengingat impor, baik yang dilakukan secara tidak jujur (unfair trade) maupun secara jujur (fair trade) tidak jarang dapat merugikan industri dalam negeri. Impor yang dilakukan secara tidak jujur dan merugikan industri dalam negeri adalah impor produk-produk asing dengan harga dumping, yaitu harga di bawah harga normal, dan impor produkproduk asing yang bersubsidi. Sedangkan impor yang dilakukan secara jujur tetapi dapat merugikan industri dalam negeri adalah impor yang jumlahnya melonjak secara cepat dan tidak wajar.

Remedi perdagangan untuk mengantisipasi produk dumping dan produk bersubsidi diwujudkan dalam bentuk pengenaan bea masuk impor tambahan, yaitu Bea Masuk Anti Dumping (BMAD) atau Antidumping Duties (ADD) dan Bea Masuk Imbalan (BMI) atau Countervailing Duties (CVD). Sedangkan remedi perdagangan untuk mengendalikan dampak impor yang melonjak

${ }^{1}$ Malangnya Komoditas Ekspor Indonesia,http://www.seputar-Indonesia.com, diakses 7 Juli 2007 
adalah tindakan pengamanan (Safeguard) berupa bea masuk tambahan dan pembatasan impor.

Secara umum penerapan remedi perdagangan didesain untuk meratakan kembali lapangan permainan (to level the playing field) yang sempat terganggu akibat adanya praktek dagang yang curang yang dimainkan produsen asing atau akibat meningkatnya secara drastis kompetisi yang fair dengan produsen asing. ${ }^{2}$ Dengan kalimat lain, tindakan Anti Dumping dan Anti Subsidi dimaksudkan untuk mengeliminasi keunggulan-keunggulan harga yang diperoleh kompetitor asing melalui praktek perdagangan curang, sedangkan tindakan pengamanan (Safeguards) didisain untuk memberikan kesempatan kepada industri domestik untuk melakukan penyesuaian dan meminimalisasi dampak-dampak yang berupa destabilisasi akibat lonjakan impor. $^{3}$

\section{Justifikasi Teoretik: Argumen Ekonomi dan Non-ekonomi}

Secara teoretik, eksistensi tindakan remedi perdagangan didasarkan pada teori-teori ekonomi dan non-ekonomi. Dalam perspektif teori ekonomi, tindakan dumping mengandung makna diskriminasi harga (price discrimination), harga yang mematikan kompetitor (predatory pricing) dan destabilitas pasar (market destabilization). ${ }^{4}$ Melalui diskriminasi harga, eksportir produk dumping membagi pasar internasional ke dalam beberapa kelompok konsumen, dan mengenakan harga yang berbeda kepada masing-masing kelompok. Dengan melakukan dumping di negara importir, eksportir memasang harga di bawah harga normal di pasar dalam negerinya sendiri agar preferensi konsumen beralih kepada produknya. Akibatnya, produk kompetitor lokal tidak mampu bersaing, dan akhirnya mati. Setelah tidak ada kompetitor lokal, eksportir produk dumping akan menaikkan harga sekehendak hatinya. Tindakan dumping juga dilakukan dalam rangka mempertahankan kapasitas terpasang dan tingginya harga di pasar negaranya sendiri sementara permintaan rendah. Dengan melakukan dumping, eksportir dapat menghindari biaya-biaya

${ }^{2}$ William H. cooper, "Trade Remedy Law Reform in the $108^{\text {th }}$ Congresds," CRS Report for Congress, 22 Juli 2003, hlm. 2.

${ }^{3}$ Ibid.

${ }^{4}$ Lihat Thomas M. Boddez and Michael J. Trebilcock, "The Case for Libarazing North American Trade Remedy," 91995) 4 Minnesota Journal of Global Trade Remedy 1, hlm. 13-18. 
penyesuaian di dalam perusahaannya dan dapat mempertahankan tingkat pekerjanya. Tindakan tersebut menyebabkan tersingkirnya kompetitor lokal dalam kurun waktu tertentu dan memaksa kompetitor lokal untuk mengeluarkan biaya-biaya yang besar untuk memasuki kembali pasar domestiknya. Muara semua tindakan dumping tersebut adalah inefisiensi alokasi sumber daya ekonomi. Untuk itulah tindakan Anti Dumping diperlukan.

Dalam perspektif ekonomi, subsidi di negara eksportir dianggap merupakan salah satu faktor yang menyebabkan terjadinya distorsi alokasi sumber daya ekonomi dan menurunnya tingkat kesejahteraan di negara importir. Dengan adanya subsidi, eksportir asing mendapatkan keunggulan kompetitif, sementara industri dalam negeri tidak. Akibatnya industri dalam negeri akan tersisih dari pasarnya sendiri. Untuk itu, adalah fair jika remedi perdagangan, dalam hal ini tindakan anti subsidi berupa CVD, secara unilateral diambil oleh negara importir dalam rangka mengatasi kegagalan pasar dan dalam rangka meningkatkan efisiensi dan maksimalisasi ekonomi.

Argumen ekonomi tindakan safeguard adalah bahwa tindakan tersebut diperlukan mengingat akibat terbukanya pasar domestik sebagai konsekuensi dari konsesi-konsesi perdagangan sebagai komitmen terhadap liberalisasi seringkali membawa dampak melonjaknya impor secara tibatiba dan dalam jumlah yang tidak wajar. Hal ini merugikan atau berpotensi merugikan industri lokal, meskipun harus diakui bahwa tidak ada unsurunsur kecurangan atau ketidakjujuran dalam praktek perdagangan eksportir asing. Remedi perdagangan, dalam hal ini tindakan safeguard baik berupa pengenaan bea masuk tambahan dan/atau pembatasan impor diperlukan untuk memberi kesempatan kepada industri lokal untuk "bernafas" dari masifnya kompetisi asing. Selama masa remedi, industri lokal akan memiliki kesempatan untuk melakukan penyesuaianpenyesuaian dengan kondisi persaingan baru, baik dengan cara menambah permodalan atau pembelian mesin-mesin baru, sehingga di akhir masa remedi industri lokal bisa bersaing dengan eksportir asing.

Selain berdasarkan teori-teori ekonomi, remedi perdagangan juga bertumpu pada teori-teori non-ekonomi, seperti teori keadilan distribusi (distributive justice) dan teori komunitarian (communitarianism). ${ }^{5}$ Dalam perspektif keadilan distribusi, masyarakat mempunyai kewajiban moral

\footnotetext{
${ }^{5}$ Ibid. hlm. 21-24.
} 
untuk tidak membuat kebijakan-kebijakan kolektif yang merugikan anggota-anggotanya yang kurang beruntung, seperti para pekerja yang mempunyai keterampilan dan gaji rendah. Remedi perdagangan, baik berupa ADD, CVD maupun tindakan safeguard, digunakan sebagai salah satu cara untuk menghindari dislokasi atau PHK. Jika karena komitmen terhadap liberalisasi perdagangan internasional, yang menghendaki adanya efisiensi ekonomi, melanggar nilai-nilai keadilan distribusi ini, maka perlindungan yang terakhir harus lebih diprioritaskan.

Dalam perspektif komunitarian, individu-individu mendapatkan identitas diri karena peran dan hubungannya di dalam komunitas. Jika industri dalam negeri dibiarkan untuk terlindas industri asing dengan cara membiarkan mereka melakukan praktek-praktek dumping dan subsidi serta membiarkan terjadinya lonjakan impor, maka dikhawatirkan akan berdampak pada kerugian perusahaan yang pada gilirannya akan mengarah pada PHK. Jika hal ini terjadi, maka ikatan-ikatan emosional komunitas serta jaringan sosial yang sudah terjalin lama akan mengalami gangguan. Oleh karena itu, nilai-nilai komunitarian ini hendaknya menjadi prioritas daripada efisiensi ekonomi. Remedi perdagangan diharapkan akan mampu untuk mempertahankan perekat ikatan dalam komunitas.

\section{Remedi Perdagangan dalam Perspektif WTO}

Teori-teori di atas tidak sepenuhnya mendapat dukungan dari para ahli, terutama para ekonom pro-liberalisasi. Hal ini karena pada umumnya para ekonom menganggap remedi perdagangan sebagai proteksi terhadap impor yang mengarah pada inefisiensi kesejahteraan ekonomi dan tidak lebih hanya diposisikan sebagai kebijakan terbaik kedua (second-best policy). Meskipun demikian, para ekonom telah menyepakati dimasukkannya remedi perdagangan ke dalam perjanjian perdagangan internasional, dalam hal ini WTO, sebagai pengecualian dengan motivasi insurance (jaminan) dan safety valve (katup pengaman). ${ }^{6}$ Pemerintah negara-negara anggota WTO akan merasa enggan untuk menandatangani perjanjian perdagangan internasional yang mengarah pada liberalisasi secara substansial, jika tidak ada jaminan perlindungan terhadap industri dalam negerinya. Selain itu pemerintah negara-negara anggota WTO akan

${ }^{6}$ Chad P. Bown, “Trade Remedies and World Trade Organization Dispute Settlement: Why are So Few Challenged?" (2005) 34 Journal of Legal Studies 515, 527. 
merasa tertekan dalam melakukan negosiasi yang berkaitan dengan komitmen liberalisasi tertentu, jika tidak ada pengecualian untuk pengamanan industri dalam negerinya. Oleh karena itu, ketentuan tentang remedi perdagangan diperlukan untuk menjaga keutuhan keseluruhan perjanjian perdagangan internasional.

Meskipun demikian, harus diakui bahwa mekanisme ini sangat berpotensi untuk disalahgunakan sebagai proteksi terselubung, sehingga kontraproduktif dengan paradigma liberalisasi perdagangan yang merupakan filosofi dasar dari WTO sendiri. Oleh karena itu, implementasi dari kedua mekanisme ini diatur dalam ketentuan-ketentuan WTO secara ketat, baik mengenai dimensi-dimensi substansi maupun proseduralnya. Secara garis besar ketentuan-ketentuan WTO tentang remedi perdagangan tersebut akan dijelaskan dalam bagian berikut.

\section{Ketentuan-ketentuan Anti Dumping}

Pengertian dan pengaturan dasar mengenai anti dumping dapat dilihat dalam Article VI GATT 1994 (Anti-Dumping and Countervailing Duties). Penjabaran lebih lanjut diatur dalam The Agreement on Implementation of Article VI of GATT 1994 atau lebih dikenal sebagai Anti Dumping Agreement (AD Agreement). Ketentuan-ketentuan tersebut mengatur secara ketat dan detail mengenai bagaimana melakukan kalkulasi apakah suatu produk merupakan produk dumping dan memenuhi syarat untuk dikenakan BMAD atau ADD; bagaimana menginisiasi kasus; bagaimana investigasi produk-produk yang diduga merupakan produk dumping, dan lain-lain.

Untuk mengenakan BMAD terhadap produk dumping harus dipenuhi syarat-syarat sebagai berikut:

1. Adanya penentuan bahwa tindakan dumping telah terjadi, termasuk estimasi margin dumping-nya.

2. Adanya kerugian material atau ancaman terjadinya kerugian material terhadap industri dalam negeri.

3. Adanya hubungan kausal yang menunjukkan bahwa tindakan dumping merupakan penyebab terjadinya kerugian atau ancaman kerugian tersebut.

Oleh karena itu, pengujian tentang kerugian (injury test) merupakan hal yang krusial. ${ }^{7}$ BMAD dapat dikenakan baik secara sementara maupun

\footnotetext{
${ }^{7}$ R. Sharma, Safeguard Measures, Module6, Commodities and Trade Division, hlm 8.
} 
tetap. Pengenaan BMAD hanya dapat dilakukan setelah dilakukan investigasi oleh otoritas yang berwenang berdasarkan prosedur sebagaimana diatur dalam Pasal 5 sampai dengan Pasal 14 AD Agreement.

\section{Ketentuan-ketentuan Anti Subsidi}

Pengaturan tentang Anti Subsidi serupa dengan pengaturan Anti Dumping, meskipun keduanya mempunyai sasaran yang berbeda; sasaran Anti Dumping adalah praktek persaingan curang yang dilakukan oleh perusahaan swasta, sedangkan sasaran Anti Subsidi adalah praktek persaingan curang yang disebabkan oleh pemberian subsidi oleh pemerintah negara eksportir, baik subsidi domestik maupun subsidi ekspor. Pengaturan tentang Anti Subsidi terdapat dalam Article VI dan XVI GATT 1994 dan The Agreement on Subsidies and Countervailing Measures (the SCM Agreement).

Article VI GATT 1994 memperkenankan negara anggota WTO untuk menggunakan tindakan Anti Subsidi untuk mengantisipasi subsidi pemerintah asing terhadap perusahaan, produksi atau ekspor barang apa pun. Perjanjian WTO mengatur secara ketat tentang bagaimana cara melakukan kalkulasi subsidi, dan mengharuskan pengenaan tindakan Anti Subsidi untuk dihentikan setelah lima tahun (the sunset provision). Perpanjangan hanya bisa dilakukan jika subsidi asing tersebut masih ada dan kerugian industri dalam negeri masih (akan) terjadi.

Tindakan Anti Subsidi yang berupa pengenaan Bea Masuk Imbalan (BMI) atau Countervailing Duties (CVD) hanya dapat dilakukan jika memenuhi persyaratan substantif sebagai berikut:

1. Adanya penentuan bahwa impor yang disubsidi telah terjadi.

2. Adanya kerugian terhadap industri dalam negeri.

3. Adanya hubungan kausal antara impor yang disubsidi dengan kerugian.

Secara prosedural, pengenaan BMI harus didasarkan pada investigasi yang dilakukan oleh otoritas, sebagaimana yang berlaku pada Anti Dumping.

\section{Ketentuan-ketentuan Safeguards}

Dalam kerangka WTO, mekanisme Safeguards diatur dalam Article XIX (Emergency Action on Imports of Particular Products) dan dijabarkan lebih lanjut dalam The Agreement on Safeguards (SG Agreement). Sebagaimana 
Anti Dumping dan Anti Subsidi, penerapan mekanisme Safeguards juga harus memenuhi beberapa persyaratan sebagai berikut.

1. Lonjakan impor, baik secara absolut maupun relatif.

2. Lonjakan impor tersebut merupakan akibat dari perkembangan yang tidak terduga dan merupakan dampak dari pemenuhan kewajiban berdasarkan perjanjian WTO.

3. Kerugian serius atau ancaman kerugian serius terhadap industri dalam negeri yang menghasilkan barang yang serupa atau barang yang langsung tersaingi.

4. Hubungan kausalitas yang menunjukkan bahwa kerugian atau ancaman kerugian tersebut benar-benar disebabkan adanya lonjakan impor.

Tindakan Safeguards hanya dapat dilakukan setelah dilakukan investigasi oleh otoritas yang kompeten berdasarkan prosedur yang telah ada sebelumnya.

Meskipun dalam beberapa hal ada persamaan dengan mekanisme Anti Dumping dan Anti Subsidi, mekanisme Safeguards berbeda dalam beberapa hal lain. Pertama, mekanisme ini tidak mengharuskan adanya praktek bisnis curang dari kompetitor asing sebagaimana dalam Anti Dumping dan Anti Subsidi. Kedua, tindakan Safeguards dapat diambil secara cepat, jika terjadi keadaan kritis. Hal ini tidak sebagaimana Anti Dumping dan Anti Subsidi yang hanya dapat diterapkan setelah dalam investigasi pendahuluan para pihak yang berkepentingan diberi kesempatan untuk memberikan tanggapan dan menunjukkan bukti-bukti. Ketiga, tindakan Safeguards dapat dilakukan selain dengan cara pengenaan bea masuk tambahan juga melalui pembatasan kuantitas impor, sedangkan tindakan Anti Dumping dan Anti Subsidi hanya dapat dilakukan melalui bea masuk tambahan. Keempat, tindakan Safeguards mengharuskan adanya kompensasi terhadap kompetitor asing yang terkena dampak tindakan tersebut. Jika tidak, maka kompetitor asing diberikan otoritas untuk melakukan penangguhan konsesi atau kewajiban lain, misalnya retaliasi, yang sepadan.

\section{Implementasi Remedi Perdagangan dalam Hukum Indonesia}

Indonesia merupakan negara anggota WTO berdasarkan ratifikasi Agreement Establishing World Trade Organization (WTO Agreement) melalui Undang-undang Nomor 7 Tahun 1994. Dengan demikian Indonesia terikat secara yuridis untuk mengimplementasikan WTO Agreement tersebut, termasuk ketentuan-ketentuan Remedi Perdagangan, dalam hukum 
nasionalnya. Negara-negara anggota WTO, termasuk Indonesia, diberikan kebebasan untuk membuat dan mengaplikasikan baik substansi maupun prosedur hukum nasionalnya sendiri. Meskipun demikian hukum nasional tersebut harus konsisten dengan ketentuan-ketentuan WTO.

Ketentuan tentang Anti Dumping dan Anti Subsidi Indonesia secara umum diatur dalam Pasal 18-20 UU No. 10 Tahun 1995 tentang Kepabeanan dan PP No. 34 Tahun 1996 tentang Bea Masuk Anti Dumping dan Bea Masuk Imbalan. Kelembagaannya diatur dalam Kepmenperindag No. 136/MPP/ Kep./7/1996.

Ada pun ketentuan tentang Safeguard diatur dalam Kepres No. 84 Tahun 2002 tentang Tindakan Pengamanan Industri Dalam Negeri dari Akibat Lonjakan Impor. Prosedur penyelidikannya diatur dalam Kepmenperindag No. 85/MPP/Kep/2/2003 tentang Tata Cara dan Persyaratan Permohonan Penyelidikan atas Pengamanan Industri Dalam Negeri dari Akibat Lonjakan Impor.

\section{Memperkuat Sistem Hukum Remedi Perdagangan Indonesia}

Ketentuan-ketentuan tentang remedi perdagangan Indonesia dituangkan dalam bentuk Peraturan Pemerintah, Keputusan Presiden) dan Keputusan Menteri. UU No. 10 Tahun 1995 memang mengatur masalah Anti Dumping dan Anti Subsidi, namun hanya bersifat sumir dan tidak mengatur masalah Safeguards. Sebagaimana yang tertuang dalam Pasal 18-20, UU tersebut hanya menyebutkan kewenangan pemerintah untuk memungut Bea Masuk Anti Dumping dan Bea Masuk Imbalan, sedangkan bagaimana pengaturannya lebih lanjut tidak diatur.

Selain inkonsisten, hal ini juga menunjukkan adanya kelemahan dalam landasan hukum. Oleh karena itu, sebaiknya landasan hukum ini diperkuat dengan mengatur keseluruhan remedi perdagangan tersebut dalam bentuk UU. Ketentuan-ketentuan WTO memberikan kebebasan kepada negara-negara anggotanya untuk melakukan harmonisasi hukum dalam bentuk hukum apapun, selama syarat-syarat umum sebagaimana diatur dalam Article X GATT 1994 dipenuhi. Syarat-syarat tersebut adalah sebagai berikut. Pertama, harmonisasi hukum dapat dilakukan melalui legislasi, regulasi, putusan pengadilan dan prosedur-prosedur administrasi. Kedua, ada kewajiban untuk mempublikasikan dengan segera instrumen harmonisasi agar segera diketahui oleh pemerintah negara-negara anggota WTO dan para pelaku perdagangan. Ketiga, sebelum dipublikasikan, 
instrumen tersebut tidak boleh diterapkan. Keempat, dalam mengadministrasikan instrumen-instrumen harmonisasi harus dilakukan secara wajar, seragam, dan tidak diskriminatif. Dilihat dari persyaratan tersebut pengaturan remedi perdagangan dalam bentuk PP, Kepres atau Kepmen, atau dalam bentuk hukum yang lain tidak menyalahi ketentuanketentuan WTO. Meskipun demikian semakin kuat bentuk hukum remedi perdagangan, semakin baik. UU adalah landasan hukum yang paling kuat di negeri ini jika dibandingkan dengan bentuk-bentuk hukum lain.

Keberadaan landasan hukum remedi perdagangan yang kuat akan lebih memberikan jaminan kepastian hukum kepada masyarakat perdagangan internasional. Kasus India - Patent Protection ${ }^{8}$ merupakan salah satu contoh yang menggugat bentuk hukum yang lemah. Dalam kasus tersebut Panel WTO menganggap bahwa instrumen hukum yang dikeluarkan oleh pemerintah India berupa Statement of Administration Action (SAA) bukan merupakan sound legal instrument (instrumen hukum yang kuat) yang memberikan jaminan pelaksanaan Perjanjian tentang Hak-hak Kekayaan Intelektual, khususnya yang berkaitan dengan paten produk-produk farmasi.

Selain lebih memberikan jaminan kepastian hukum, landasan hukum yang kuat seperti UU juga memungkinkan untuk menjadi landasan hukum yang mengatur pembentukan otoritas remedi perdagangan yang kuat pula. Sebagaimana yang diisyaratkan dalam footnote 3 dari Article 2.2.1 AD Agreement, otoritas remedi perdagangan harus diartikan sebagai otoritas tingkat tinggi. Jika otoritas-otoritas tingkat tinggi lain yang berbentuk Komisi seperti Komisi Pengawas Persaingan Usaha (KPPU), Komisi Pemberantasan Korupsi (KPK), Komisi Pemilihan Umum (KPU), Komisi Yudisial, Komisi Kejaksaan, Komisi Kepolisian, dan lain-lain, dibentuk berdasarkan UU, maka otoritas remedi perdagangan pun sebaiknya dibentuk berdasarkan UU pula.

Di Canada pengaturan setingkat UU tentang remedi perdagangan terdapat dalam The Special Import Measures Act (SIMA) dan the Canadian International Trade Tribunal Act. Sedangkan di Amerika Serikat remedi perdagangan diatur dalam the Tariff Act of 1930, sebagaimana telah diamandemen dengan the Trade Agreements Act of 1979, the Trade

${ }^{8}$ India - Patent Protection for Pharmaceutical and Agricultural Chemical Products (India - Patent Protection), Panel Report, WT/DS50/R, 5 September 1997; Appellate Body Report, WT/DS50/AB/R, 19 December 1997. 
and Tariff Act of 1984, the Omnibus Trade and Competitiveness Act of 1988, dan the Uruguay Round Agreements Act of 1994 ("URAA").

Meskipun ketentuan-ketentuan substantif tentang remedi perdagangan Indonesia, baik yang terkait dengan Anti Dumping, Anti Subsidi maupun tindakan Pengamanan (Safeguards) sudah mengacu kepada ketentuanketentuan WTO, namun masih ada beberapa hal yang belum sepenuhnya konsisten, misalnya tentang definisi-definisi: barang dumping; kerugian; dan industri dalam negeri. Inkonsistensi juga terjadi dalam implementasi, misalnya dalam hal penetapan pengenaan BMAD selalu melewati batas waktu yang diterapkan secara internasional. Dalam bidang Safeguards, penyelidikan yang telah diselesaikan dan tinggal diputuskan pengenaan bea masuknya menjadi tertunda-tunda penetapannya.

Oleh karena itu, hukum remedi perdagangan harus diperkuat sehingga konsisten dengan ketentuan-ketentuan WTO. Inkonsistensi akan membawa konsekuensi dituntutnya Indonesia oleh negara lain di DSB. Sebagai ilustrasi, ketika Amerika Serikat (AS) mengeluarkan Continued Dumping and Subsidy Offset Act of 2000, atau lebih dikenal sebagai Byrd Amendment, yang tidak sesuai dengan standar WTO, negara adidaya tersebut dituntut oleh beberapa negara, termasuk Indonesia. ${ }^{9}$ Berdasarkan Byrd Amendment, pendapatan pemerintah AS yang diperoleh dari BMAD yang dipungut dari perusahaanperusahaan asing didistribusikan kepada perusahaan-perusahaan dalam negeri yang mengajukan petisi untuk investigasi dumping. Akibatnya, tahun 2001 AS mendistribusikan lebih dari US\$ 230 juta kepada 900 perusahaan; tahun 2002, US\$ 330 juta diserahkan kepada 1200 perusahaan; dan pada tahun 2003, US\$ 190 juta dibayarkan kepada 1800 perusahaan. Australia, Brazil, Chile, Uni Eropa, India, Jepang, Korea Selatan, Thailand dan Indonesia mengajukan gugatan kepada DSB karena pemberlakuan Byrd Amendment merupakan insentif keuangan bagi industri domestik untuk meminta penyelidikan adanya dumping atau subsidi pada produk-produk impor. Baik Panel maupun Appellate Body mengabulkan mayoritas gugatan para penggugat.

Dalam kasus Argentina - Footwear ${ }^{10}$ Uni Eropa dan beberapa negara

${ }^{9}$ United States - Continued Dumping and subsidy Offset Act of 2000 (Byrd Amendment); Panel Report, WT/DS217/R, WT/DS234/R, 16 September 2002; Appellate Body Report, WT/DS217/AB/R, WT/DS234/AB/R, 16 January 2003.

${ }^{10}$ Argentina - Safeguard Measures on Imports of Footwear (Argentina - Footwear), Panel Report, WT/DS121/R, 25 June 1999; Appellate Body Report, WT/DS121/AB/ R, 14 Desember 1999. 
yang bertindak sebagai pihak ketiga seperti Brazil, Paraguay, Uruguay, Amerika Serikat dan Indonesia menggugat Argentina di WTO. Gugatan didasarkan atas tindakan Argentina yang mengenakan tindakan Safeguards sementara dan tetap terhadap produk-produk alas kaki dari negara-negara penggugat. Produk-produk alas kaki dari negara-negara penggugat dikenakan bea masuk US\$ 12.00 per unit dengan nilai rata-rata unit antara US\$ 11.00 dan US\$19, sehingga ad valorem-nya melebihi $70 \%$.

Menurut Indonesia, the Argentine National Foreign Trade Commission (ANFTC) tidak dapat membuktikan bahwa industri dalam negeri menderita kerugian serius, dan gagal untuk menunjukkan adanya hubungan kausal antara peningkatan impor dengan kerugian serius. Dalam menentukan kerugian serius atau ancaman kerugian serius, ANFTC tidak menunjukkan "analisa kasus yang detail" atau tidak menguji "faktor-faktor yang relevan". Panel menyimpulkan bahwa pengenaan Safeguards tetap berdasarkan penyelidikan dan penetapan Argentina tidak konsisten dengan Article 2 SG Agreement.

Inkonsistensi dalam implementasi ketentuan-ketentuan WTO juga dapat dilihat dalam kasus US - Definitive Safeguard ${ }^{11}$. Tanggal 5 Maret 2002, Amerika Serikat mengeluarkan Proclamation N. 7529 yang diberi nama "To Facilitate Positive Adjustment to Competition from Imports of Certain Steel Products." Berdasarkan proklamasi ini, AS mengenakan Safeguards tetap pada 20 Maret 2002 sebesar 8 sampai 30\% terhadap impor beberapa produk baja tertentu yang berasal dari negara-negara penggugat, termasuk China. Karena pengenaan Safeguards tersebut dilakukan dengan cara yang inkonsisten dengan ketentuan WTO, Amerika Serikat dinyatakan kalah.

Contoh-contoh kasus tersebut mengimplikasikan bahwa substansi pengaturan dan implementasi ketentuan-ketentuan remedi perdagangan Indonesia pun harus konsisten dengan ketentuan-ketentuan WTO.

Kelemahan lain dari sistem hukum remedi perdagangan Indonesia menyangkut kelembagaan atau otoritas (struktur hukum), terutama menyangkut independensi Komite Anti Dumping Indonesia (KADI) maupun Komite Pengamanan Perdagangan Indonesia (KPPI). Baik KADI maupun KPPI saat ini masih belum berlaku sebagai "institusi pengadilan" atau "tribunal perdagangan" di tingkat nasional. Keduanya masih

${ }^{11}$ United States - Definitive Safeguard Measures on Imports of Certain Steel Products (US - Definitive Safeguard), Panel Report, WT/DS248/R, WT/DS249/R, WT/DS252/ R, WT/DS253/R, WT/DS254/R, WT/DS258/R, WT/DS259/R. 
berfungsi sebagai lembaga "rekomendasi". Akibatnya, efektivitas, efisiensi, dan profesionalisme institusi belum bisa dicapai secara optimal.

Keberadaan lembaga remedi perdagangan Indonesia yang independen, yang akan berfungsi sebagai "institusi pengadilan" atau "tribunal perdagangan", sangat diperlukan mengingat beberapa hal. Pertama, sebagaimana dalam sistem peradilan konvensional, lembaga remedi perdagangan yang independen akan terbebas dari intervensi-intervensi ekonomi dan politik dari luar, sehingga keputusan untuk menerapkan BMAD, BMI dan tindakan Safeguards benar-benar didasarkan pada hasil investigasi yang obyektif. Kedua, sebagai konsekuensi dari yang pertama, mekanisme pengambilan keputusan pun akan menjadi lebih singkat, karena otoritas remedi perdagangan ini menjadi penanggung jawab keseluruhan mekanisme pengambilan keputusan. Ketiga, konsekuensi lebih jauh dari yang pertama dan kedua, pembentukan otoritas remedi perdagangan yang profesional, dengan sumber daya manusia penuh waktu, akan lebih memungkinkan, karena intervensi-intervensi ekonomi politik tidak lagi mendominasi. Keempat, meskipun independen, otoritas remedi perdagangan tidak akan mengabaikan kepentingan nasional, karena kepentingan nasional justru akan dipertimbangkan secara lebih komprehensif. Adapun contoh-contoh otoritas remedi perdagangan yang independen di negara lain di antaranya the U.S. International Trade Commission ("ITC") dan the Canadian International Trade Tribunal ("Tribunal").

Dari segi budaya atau kultur hukumnya, masih ada permasalahan yang cukup menentukan yaitu belum proaktifnya kalangan usahawan dalam mengantisipasi terjadinya penurunan kinerja akibat dari impor yang melonjak atau akibat dari produk dumping dan produk asing bersubsidi di Indonesia. Demikian juga sikap proaktif belum begitu nampak dalam rangka mengantisipasi dan mencari solusi mana kala produkproduknya dituduh dumping atau bersubsidi di luar negeri atau manakala produknya dilakukan penyelidikan untuk dikenakan tindakan Safeguards.

Untuk itu perlu adanya penguatan budaya hukum di kalangan para pengusaha ini dengan cara sosialisasi agar mereka mengetahui dan menyadari serta menggunakan instrumen hukum remedi perdagangan ini untuk melindungi dirinya. Para pengusaha juga perlu diberikan bekal pengetahuan dan keterampilan dalam menggunakan instrumen hukum tersebut, misalnya melalui training atau lokakarya. Selain itu pemberian pendampingan dan, jika perlu, advokasi yang memadai. Khusus untuk 
pengusaha kecil dan menengah yang bersangkutan dengan masalah remedi perdagangan, perlu juga ada semacam Trade Remedy Assistance Office yang menyediakan informasi hukum dan bantuan teknis. Bantuan teknis meliputi nasihat dan bantuan informal termasuk dukungan hukum dalam menentukan langkah-langkah yang tepat untuk menggunakan remedi perdagangan, menyiapkan petisi dan keluhan, dan memperoleh remedi. Sangat penting pula bagi pemerintah untuk menganggarkan dalam pos APBN untuk pembentukan dana berjaga-jaga, sebagaimana diusulkan ekonom Imam Sugema, yang akan digunakan untuk membantu pengusaha yang terkena tuduhan dumping, subsidi dan tindakan Safeguard. ${ }^{12}$ Hal ini diperlukan mengingat banyaknya jumlah tuduhan yang dialamatkan ke Indonesia, sementara kemampuan dalam negeri untuk "melawan" masih rendah, antara lain karena dana yang rendah. ${ }^{13}$

\section{Urgensi Perlindungan Industri Dalam Negeri}

Baik tindakan dumping maupun subsidi yang dilakukan eksportir asing dan lonjakan impor yang signifikan di Indonesia, serta tuduhan dumping dan subsidi dan investigasi untuk pengenaan Safeguards terhadap produkproduk Indonesia di luar negeri mengakibatkan kerugian luas terhadap industri dalam negeri, khususnya, dan masyarakat serta negara tuan rumah pada umumnya. Kerugian tersebut berupa semakin sempitnya pangsa pasar produsen Indonesia. Hal ini akan menimbulkan dampak domino yang berupa kemerosotan pendapatan yang menyebabkan penurunan kemampuan investasi. Lebih lanjut hal tersebut menimbulkan penurunan daya produksi dan daya ekspor. Pada gilirannya pengangguran bertambah dan daya hidup perusahaan menurun.

Hal ini mengimplikasikan bahwa penggunaan instrumen remedi perdagangan secara proaktif akan sangat membantu melakukan upayaupaya perlindungan dan sekaligus remedi bagi industri dalam negeri. Selama ini kecenderungan menuju ke arah sebaliknya, dengan fakta-fakta sebagai berikut. Selama periode 2002-2006, inisiasi Anti Dumping, Anti Subsidi dan tindakan Safeguard terhadap Indonesia sebanyak 69, terdiri dari Anti Dumping 61, Anti Subsidi 2 dan Safeguard 2; sedangkan inisiasi

${ }^{12}$ Bapekki Depkeu, "AS Masih Tuduh Indonesia Soal Empat Subsidi Ekspor", Bisnis Indonesia, 13 Oktober 2006.

${ }^{13}$ Ibid.

${ }^{14}$ WTO Secretariat, Trade Policy Review, WT/TPR/S/184, 23 May 2007, hlm 51. 
Anti Dumping, Anti Subsidi dan Safeguard oleh Indonesia terhadap produk asing hanya 32, terdiri dari Anti Dumping 29 dan Safeguard 3. ${ }^{14}$

Dalam penyelesaian sengketa di DSB, dari 102 kasus dalam periode 1995-2006, hampir setengahnya merupakan kasus remedi perdagangan. Dalam kurun waktu 2005 dan 2006, kasus-kasus remedi perdagangan meningkat tajam; dua pertiga dari kasus-kasus yang diajukan di WTO sejak awal 2005 (17 dari 27 kasus) merupakan kasus remedi perdagangan. ${ }^{15}$ Sejalan dengan itu, hampir dua pertiga kasus yang sedang berjalan (12 dari 19 kasus) juga merupakan kasus remedi perdagangan. ${ }^{16}$ Demikian pula 5 dari 8 kasus aktif dalam tahap konsultasi formal yang berpotensi untuk meminta dibentuk panel, juga kasus remedi perdagangan. ${ }^{17}$ Sementara itu, dalam sekian banyak kasus di WTO tersebut, Indonesia hanya terlibat dalam 3 kasus saja, itu pun hanya dalam satu kasus Indonesia bertindak sebagai pihak mandiri, sedangkan dalam dua kasus lainnya Indonesia hanya bertindak sebagai pihak ketiga, atau turut menggugat bersama-sama dengan negara lain.

Fakta-fakta tersebut menunjukkan bahwa, mayoritas inisiasi anti dumping dan anti subsidi saat ini banyak ditujukan terhadap produkproduk Indonesia, sementara Indonesia masih kurang proaktif dalam mengajukan inisiasi terhadap produk-produk asing. Hal ini menunjukkan pula bahwa mengimplementasikan ketentuan-ketentuan remedi perdagangan membutuhkan dana yang besar. Ketiga, mengingat detail dan kompleksnya informasi yang harus dikumpulkan, pada umumnya negara berkembang, termasuk Indonesia mengalami kesulitan untuk mengajukan inisiasi untuk penyelidikan di negaranya sendiri dan menindaklanjutinya sehingga berhasil, karena pengumpulan dan analisis fakta-fakta yang mendukung sangat mahal. Selain itu staf yang menangani kasus-kasus dumping, subsidi dan lonjakan impor yang tersedia, juga pada umumnya sangat terbatas. Hal ini kontras dengan negara-negara maju seperti AS dan Uni Eropa (UE), yang memiliki personil dan sumber daya yang memadai untuk menangani kasus-kasus remedi perdagangan.

${ }^{15}$ Bruce Wilson, Dispute Settlement in the WTO: An Update, Paper pada Presentasi di Washington International Trade Association, 16 Nopember 2006, hlm 10.

${ }^{16}$ Ibid.

${ }^{17} \mathrm{Ibid}$. 


\section{Penutup}

Kesemua hal tersebut di atas mengindikasikan urgennya perlindungan industri dalam negeri, salah satunya melalui penguatan sistem hukum remedi perdagangan. Dengan penguatan sistem hukumnya, diharapkan akan menjadi modal awal untuk mendorong pemerintah dan pengusaha lebih proaktif dalam melindungi industri dalam negerinya. Negara berkembang seperti Indonesia belum mampu menyaingi apalagi mengalahkan negara-negara kuat baik secara ekonomi, politik maupun teknologi, tetapi secara hukum sangat mungkin, dan dalam kenyataannya negara-negara kuat seperti Amerika, Uni Eropa, Jepang, dan Canada tidak jarang dikalahkan oleh negara-negara berkembang di forum DSB WTO. Oleh karena itu, paralel dengan penguatan daya saing industri dalam negeri, penguatan sistem hukum remedi perdagangan pun harus menjadi prioritas.

\section{Daftar Pustaka}

Bapekki Depkeu, “AS Masih Tuduh Indonesia Soal Empat Subsidi Ekspor", Bisnis Indonesia, 13 Oktober 2006.

Boddez, Thomas M. dan Michael J. Trebilcock, "The Case for Liberalizing North American Trade Remedy," (1995) 4 Minnesota Journal of Global Trade Remedy 1.

Cooper, William H., “Trade Remedy Law Reform in the $108^{\text {th }}$ Congress," CRS Report for Congress, 22 Juli 2003'

Disperindagkop Prop. DIY, Malangnya Komoditas Ekspor Indonesia, http:/ /www.seputar-Indonesia.com, diakses 7 Juli 2007.

Rosadi, Muhammad Riza, Penerapan Sistem Ekonomi Islam melalui Khilafah Islamiyah, http://syariahpublications.com/2007/06/01, diakses 3 Agustus 2007.

Brown, Chad P., "Trade Remedies and World Trade Organization Dispute Settlement: Why are So Few Challenged?" (2005) 34 Journal of Legal Studies

Sharma, R., Safeguard Measures, Module 6, Commodities and Trade Division. 
WTO Secretariat, Trade Policy Review, WT/TPR/S/184, 23 May 2007.

Wilson, Bruce, Dispute Settlement in the WTO: An Update, Paper pada Presentasi di Washington International Trade Association, 16 Nopember 2006.

\section{Putusan-putusan WTO}

India - Patent Protection for Pharmaceutical and Agricultural Chemical Products (India - Patent Protection), Panel Report, WT/DS50/R, 5 September 1997; Appellate Body Report, WT/DS50/AB/R, 19 December 1997.

United States - Continued Dumping and subsidy Offset Act of 2000 (Byrd Amendment); Panel Report, WT/DS217/R, WT/DS234/R, 16 September 2002; Appellate Body Report, WT/DS217/AB/R, WT/DS234/AB/R, 16 January 2003.

Argentina - Safeguard Measures on Imports of Footwear (Argentina - Footwear), Panel Report, WT/DS121/R, 25 June 1999; Appellate Body Report, WT/DS121/AB/R, 14 Desember 1999.

United States - Definitive Safeguard Measures on Imports of Certain Steel Products (US - Definitive Safeguard), Panel Report, WT/DS248/R, WT/ DS249/R, WT/DS252/R, WT/DS253/R, WT/DS254/R, WT/DS258/ R, WT/DS259/R. 